\title{
Factors Affecting the Implementation of the Makassar City Water Supply Regional Public Companies Partnership Program
}

\author{
Muh Zulkifli Tahir ${ }^{1}$, Sulaiman Asang ${ }^{1}$, Thahir Haning ${ }^{1}$, Nurdin Nara ${ }^{1}$ \\ ${ }^{1}$ Public Administration, Faculty of Social and Political Sciences, Hasanuddin University, \\ Indonesia
}

Received: March 14, 2021

Received in Revised: April 9, 2021

Accepted: April 20, 2021

\begin{abstract}
This study aims to describe the factors that influence the implementation of the Regional Public Companies Water Drinking Partnership Program in Makassar City. This study used qualitative research methods. This research is to understand the implementation of the Partnership Program for the Regional Public Drinking Water Company in Makassar, taking the research location in the city of Makassar which is the capital of South Sulawesi Province, specifically the office of the Regional Public Company for Drinking Water in Makassar City. The process of collecting data in research is observation and interviews, the data collection method is used in this research method by interviewing the respondents who are related to the location to obtain information about the problems of this research. Regional Public Companies Drinking Water has a commitment to be ready to serve and strive to improve satisfying service for customers. Regional Public Companies no longer needs to bother collaborating one by one with other parties for the Online Payment System. There are still factors that hinder the partnership program.
\end{abstract}

Keywords: Partnership, Program, Regional Public Companies

\section{Introduction}

The concept of partnership can be seen in the context of community development in the provision of excellent service. The community demands the availability of good services, good quality, good performance and expects to be served by a results-oriented government, while the special government capacity in governance at the regional level appears to be limited. In partnership program learning, a case study approach can be used. Through the case study, a conclusion can be drawn that is used for learning by comparing the theoretical framework of cooperation with the conceptual issues of the public-private partnership problem. In the context of public services, the Partnership provides many things that can be obtained for public and private sector administrators, especially in access to resources. Pierre (2000); Mustafa, (2014) argued that by creating public-private partnerships another form of joint projects, public services tapped into resources they previously did not have access to. The involvement of the private sector in the Regional Public Companies Water Drinking City of Makassar is an economic reform program, there is political commitment at all levels of government, there is consensus among stakeholders and public authorities having clear objectives including in the decision-making process, so that the partnership program with the private sector must be well prepared. consider the risks that arise from both economic, political and legal aspects. according to what is known by Grindle (1980) and Akib (2010) that the implementation process will only start when the goals and objectives have been set, the activity program has been structured and funds are ready to be distributed to achieve the target. policy implementation links between policy objectives and their realization with the results of government activities. Regional Public Companies Water Drinking Makassar City as a public service company owned by the Makassar 
city government, whose type of business is in the field of clean water supply services, is expected to continue to innovate to provide the best service improvement to the people of Makassar City in accordance with the Company's mission, namely to provide and pay attention to the best water quality for the community to serve and trying to improve satisfactory service for customers as well as work peace and welfare of professional company employees with competent and highly competitive resources. Implementation are actions carried out by individuals, officials, government or private groups that are directed at achieving the objectives specified in the policy decision. Implementation of an important stage in the public policy process, a policy or program must be carried out so that it has the desired objectives (Carden, 2009; Sapru, 2011; Miller \& McTavish, 2013). Implementation is public administration explaining that implementation is carried out together to run the program in order to achieve the expected impact or goal (O'Toole, 2000; Hill \& Hupe, 2002). This study aims to describe the factors that influence the implementation of the Regional Public Companies Water Drinking Partnership Program in Makassar City.

\section{Methods}

This study used qualitative research methods. This research is to understand the implementation of the Partnership Program for the Regional Public Drinking Water Company in Makassar, taking the research location in the city of Makassar which is the capital of South Sulawesi Province, specifically the office of the Regional Public Company for Drinking Water in Makassar City. The process of collecting data in research is observation and interviews, the data collection method is used in this research method by interviewing the respondents who are related to the location to obtain information about the problems of this research. individuals as the purpose of the interview are called informants, who understand very well in this study. The informants of this research are the Director General of Drinking Water, Head of Legal Section, Head of Subscription Relations Section, Head of Administration and Electronic Data Processing (PDE) and Electronic Data Processing (PDE) Staff. Data analysis activities are carried out through data reduction, data presentation and drawing conclusions.

\section{Results and Discussion}

\section{Factors Supporting the Implementation of the Makassar City Water Supply Regional Public Companies Partnership Program}

The results of the implementation of the Makassar City Drinking Water Regional Public Companies Partnership Program from the Content of Policy, the factors that support the implementation of the Makassar City Water Drinking Regional Public Companies Partnership Program are:

\section{Intersts Affected}

The interest of Regional Public Companies Drinking Water in Makassar City as a company that provides clean water and BUMD owned by the Makassar City government, with the Online Payment System Partnership Program, is a positive image for the company in improving services with this partnership program with many choices of ways to pay water bills so as to minimize the risk of delays in bill payment so that it has a negative impact on the company's revenue which can affect the company's performance. Information Technology (IT) companies that are partners with Regional Public Companies have a business interest to gain profit from this cooperation which has been regulated in an agreement in accordance with applicable regulations. And carry out its roles and responsibilities as best as possible to be able to cooperate with a long time. 


\section{Type of Benefits}

Positive benefits in the implementation of this Partnership Program are a supporting factor in this program, based on the data that researchers have obtained that the implementation of this Partnership Program has a positive impact on Program Implementers and Policy Recipients. The benefits of Regional Public Companies Kota Drinking Water as Program Implementer are less budget allocation expenditure, efficiency of company work in terms of input and processing of bill data, increased service to customers, reducing the risk of delays in payment of water bills, increasing company revenue from the main source of water bills.

Then the benefits received by Information Technology (IT) companies in partnership with Regional Public Companies are business benefits to gain profits / benefits from this program. Customers of Regional Public Companies Drinking Water in Makassar City as a result of the implementation of this policy provide positive benefits because there are many ways to pay water bills with this collaboration. Payments are easier, faster and safer. The risk of customers being late in paying bills is small, so apart from the risk of late fees and the last risk is termination of the water line.

\section{Extent of Change Envisioned}

The degree of change to be achieved in the implementation of this Program is a supporting factor for the successful implementation of this Partnership. Due to the rapid progress of technological developments, so that changes in society in access to technology are increasingly varied. The degree of change to be achieved in this Partnership Program is very clear that the objective of implementing this partnership program is that customers make it easier for customers to pay their water bills easily, quickly and safely so that there are delays in payments with the number of customers reaching 175 thousand. Partnership for Regional Public Companies for Drinking Water in Makassar City.

\section{Program Implementors}

The Program Implementer is a supporting factor in the successful implementation of the Partnership Program, that the Program Executor is competent and has expertise in his field. Based on research data, it is found that Regional Public Companies Drinking Water as a Biller Company bills a number of bills according to water usage. Regional Public Companies Drinking Water is a drinking water company that exists throughout the territory of Indonesia and without any competition in the company that provides clean water for many people belonging to the local area.

Information Technology (IT) Company, in partnership with Regional Public Companies Air Drinking Makassar City, is a technology company that has experience and expertise in this field as a switching and biller aggregator company that collaborates with various partners to support the company's work program. Supporting factors in the implementation of the Regional Public Companies Partnership Program in the context of its implementation (Contex Of Implementation)

\section{Power, Interest, and Strategies of Actors Involved}

Actor's strategy as program implementer influences in program implementation, the actors involved in this program continue to monitor the development of partners by evaluating each year the performance of the partner companies based on the data obtained by researchers at the Administration and Electronic Data Processing and Regional Public Companies Directors Continue to coordinate with and control the nets of this program by receiving reports about the evaluation of this program the Administration and Electronic Data Processing. 
The influence of the power and interests of Regional Public Companies Air Drinking City of Makassar and the Companies that are partners to support the implementation of the partnership program goes according to what is to be achieved. The power of Regional Public Companies drinking water as a company owned by the regional government which becomes a single company without any business competition with other parties in the provision of clean water for the community at large. The interest in implementing this program is also a supporting factor. Whereas the interest of Regional Public Companies in improving service to customers and work efficiency of employees is to maximize revenue for Regional Public Companies Air Drinking City of Makassar and to form a positive image in society. The success of this Program can continue to be implemented in the interests of those who are implementing the Program. Information Technology (IT) companies partnering in the Regional Public Companies Drinking Water of Makassar City have a business interest in gaining profits for the company as well as enhancing a good image for IT companies with experience in online payment system technology.

\section{Instituion and Regime Characteristics}

The institutions and regimes that are in charge of implementing the Partnership Program are appropriate, namely the Regional Public Companies for Drinking Water of Makassar City as a regional owned company and the purpose of establishing a company based on the Regional Regulation to carry out general use of quality water and water sources and to meet the drinking water needs of the Makassar City community especially for customers . As well as providing benefits for the development of the regional economy by increasing local revenue. As well as the Regional Public Companies Air Drinking City of Makassar serving and trying to improve satisfying service for customers.

Based on the results of the research on the characteristics of Regional Public Companies Drinking Water as a single company without any business competition, and the most important company income is Water Bills, a maximum program is needed to benefit from the Online Billing Program to maximize revenue from bill payments to improve company performance and contribution. Regional Original Income (PAD).

\section{Compliance and Responsiveness}

Obedience / Compliance of the Regional Public Companies Drinking Water in Makassar City is a supporting factor in the implementation of the Online Bill Payment Partnership Program, that the results of the data obtained by researchers indicate that there is consistent collaboration with IT companies that have partnered with long periods of cooperation with the company, and also compliance Regional Public Companies Air Drinking to increase cooperation with other partners such as BUMN / BUMD Banks, private banks and non-bank companies to further expand the online bill payment network with the aim of making it easier for customers to make bill payments and maximize company revenue.

The responsiveness / response of the recipients of this Partnership Program with a good response, with the observations of researchers in the Regional Public Companies Service area, no longer visible queues of customers piling up at the payment counters. Customers have many alternatives to pay their water bills to pay on time easily, quickly and safely.

\section{Inhibiting Factors for the Implementation of the Makassar City Drinking Water Regional Public Companies Partnership Program}

Grindle (1980) stated that realizing the goals and objectives in the Policy Implementation process is determined by the availability of budget allocations and program planning. But in order to achieve more maximum results in the implementation of the Regional Public 
Companies Drinking Water Partnership Program in Makassar City, based on the data obtained, there are several factors that become obstacles to getting maximum results. Factors that hinder the process of Partnership for the Regional Drinking Water Company Partnership in Makassar in terms of Content Of Policy, namely;

\section{Type of Benefits}

In a policy must provide benefits for policy recipients. In Implementing the Online Payment System Program or the Online Payment System, not all of the benefits received are felt in this program, because in Regional Public Companies Drinking Water is divided based on water use categories, so the R1 and R2 Category Customers are the very simple and low-income house category direct payment to the official service counter of the Makassar City Drinking Water Regional Public Companies. This category will experience difficulties with the use of online bill payment services due to additional admin and internet quota fees, as well as difficulties with how to pay bills.

\section{Extent of Change Envisioned}

The program set expects that there will be changes in the customers of Regional Public Companies Air Drinking City of Makassar, Regional Public Companies customers as the beneficiaries of the implementation of this partnership program, in the implementation of customers who are in the R1 and R2 categories there is no significant change, because in the category they do not take advantage of their bill payments. via online but pay directly at the Regional Office of Regional Public Companies Services. So that the expected changes are not evenly distributed, and the ones who feel the most change are customers of certain categories such as industry, hospitality and elite residential complexes who are able to take advantage of online bill payments and also correct financial reporting for business categories.

\section{Program Implementers}

Program Implementer in the Implementation of this Partnership Program Regional Public Companies Water Drinking Makassar City, in the organizational structure of the Regional Public Companies Water Drinking Agency there is no section specifically related to the field of Partnership. As well as the factors that influence the implementation of this partnership program that the implementation of the partnership program is less socialized and education is more massive, the problem of this partnership program is mainly the problem of correct payment methods so as to achieve maximum results in this program is less achieved apart from the Customer category factor. And the Technology Information (IT) Company that partners with the Regional Public Companies Water Drinking City of Makassar as well as the Implementer of the Partnership Program is not maximal in conducting socialization and education related to online payment methods. Meanwhile, Obstructing Factors in the Implementation of the Partnership Program for the Regional Public Companies Drinking Water in Makassar City from the Contex of Implementation variable

\section{Power, Interests, and Strategies of Actors Involved}

Implementation of the Partnership Program at Regional Public Companies Water Drinking City of Makassar, based on data obtained in the research location and data analysis that the implementation of the Partnership Program has been going well but to get maximum results from this implementation is due to the factors of power, interest and strategy of actors involved in their functions and roles. considered less than the maximum. The Board of Directors at Regional Public Companies as an important actor in the Partnership Program does not give duties / orders to the relevant sections to further socialize and educate this partnership program 
in the community, this problem is a factor that researchers get as a factor that becomes an obstacle to getting more maximum results.

The act of converting decisions into operational actions within a certain time and in continuing efforts to achieve small and big changes that have been determined by program decisions and implementation of policies after the law has been enacted and budget allocations of funds to finance the program Policy implementation is a crucial stage in public policy process. a policy program must be implemented in order to have the desired impact or goal (Van Meter \& Van Horn, 1975; Sabatier \& Mazmanian, 1980; Vedung, 2017). Policy implementation is seen in a broad sense, is the stage of the policy process immediately after the enactment of a law in which various actors, organizations, procedures and techniques work together to carry out policies in an effort to achieve policy or program objectives and are basically implementation. program.

\section{Conclusion}

Supporting Factors in the Implementation of the Regional Public Companies Drinking Water Partnership Program in Makassar City, seen from the Content of Policy, there are Intersts affected. Regional Public Companies Drinking Water has a commitment to be ready to serve and strive to improve satisfying service for customers. Regional Public Companies no longer needs to bother collaborating one by one with other parties for the Online Payment System and more importantly, there is recording and reporting of incoming data and funds, and also maximizing company revenue from the many ways to pay water bills which are the main source of income. Information Technology company partners, Characteristics of Ruling Institutions and Regimes. Regional Public Companies Drinking Water City of Makassar as a Regional Company owned by the Government of Makassar City which was established to provide clean water services for the needs of the community with equal distribution of services. Powers, Interests and Actors involved. Based on the results of research and discussion, there are still factors that hinder the partnership program of the Regional Public Companies Drinking Water of Makassar City in the implementation of this partnership program which is not maximal in education and outreach about this Partnership Program. Likewise, corporate partners lack of socialization to get maximum results. Regional Public Companies Directors do not pay more attention to their subordinates for education and socializing this Partnership Program.

\section{References}

Akib, H. (2010). Implementasi Kebijakan: Apa, Mengapa, dan Bagaimana. Jurnal Administrasi Publik, 1(1), 11.

Carden, F. (2009). Knowledge to policy: Making the most of development research. IDRC.

Grindle, M. S. (1980). Politics and policy implementation in the Third World. In Princeton University Press (Vol. 4880). Princeton University Press.

Hill, M., \& Hupe, P. (2002). Implementing public policy: Governance in theory and in practice. Sage.

Miller, K. J., \& McTavish, D. (2013). Making and managing public policy. Routledge.

Mustafa, A. T. (2014). Efektivitas Program Kemitraan Pengembangan Usaha Mikro,Kecil dan Menengah. Universitas Hasanuddin Makassar.

O'Toole Jr, L. J. (2000). Research on policy implementation: Assessment and prospects. Journal of public administration research and theory, 10(2), 263-288.

Pierre, J. (Ed.). (2000). Debating governance: Authority, steering, and democracy. OUP Oxford. 
Sapru, R. K. (2011). Public policy: Art and craft of policy analysis. PHI Learning Pvt. Ltd.

Van Meter, D. S., \& Van Horn, C. E. (1975). The policy implementation process: A conceptual framework. Administration \& Society, 6(4), 445-488.

Vedung, E. (2017). Public policy and program evaluation. Routledge. 